\title{
Comparison of Wavelet Family Performances in ECG Signal Denoising
}

\section{Perbandingan Unjuk Kerja Transformasi Wavelet dalam Denoising Sinyal ECG}

\author{
Octa Heriana $^{\text {a, } *}$ and Ali Matooq Al Misbah ${ }^{\text {b }}$ \\ ${ }^{a}$ Pusat Penelitian Elektronika dan Telekomunikasi, Lembaga Ilmu Pengetahuan Indonesia. \\ Komplek LIPI Gd 20, Jl Sangkuriang 21/54D, Bandung 40135, Indonesia \\ ${ }^{b}$ Electrical Engineering Department, King Fahd University of Petroleum and Minerals. \\ Dhahran 31261, Saudi Arabia
}

\begin{abstract}
The heart is considered the most important organ of our body that controls the circulation of blood throughout the body. Measured heartbeat signals can be further analyzed in order to know the health condition of a person. The challenge of ECG signal measurement and analysis is how to remove the noises imposed on the signal that is interfered from many different sources, such as internal noise in sensor devices, power line interference, muscle activity, and body movements. This paper implemented wavelet transform to reduce the noise imposed on the ECG signal to get a closely actual heart signal. ECG data used in this research are three digitized recorded ECG data obtained from MIT-BIH Arrhythmia Database. The first step is generating the noisy ECG signal as the input system by adding $1 W$ WGN signal into the original ECG signal. Then DWT is applied to extract the noisy ECG signal. Some DWT's parameters, threshold selection (rule, type, rescaling), decomposition level, and desired wavelet family are varied to get the best denoised output signal. All results are recorded to be compared. Based on the results, the best DWT parameter for ECG signal denoising is obtained by Symlet wavelet when the decomposition level is set to 3 , with soft thresholding, in rigrsure thresholding rule.
\end{abstract}

Keywords : denoising, ECG, signal, wavelet.

Abstrak

Organ jantung adalah bagian dari tubuh yang memiliki peran penting yang berfungsi untuk mengendalikan peredaran darah keseluruh tubuh. Pengamatan terhadap cara kerjanya adalah bidang studi yang sangat menarik untuk dipelajari sejak bertahuntahun yang lalu. Seiring perkembangan teknologi, pola sinyal detak jantung dapat diukur dan dianalisis lebih lanjut untuk mengetahui kondisi kesehatan seseorang. Adapun tantangan yang ditemui dalam pengukuran dan analisis sinyal EKG adalah bagaimana menghilangkan atau meminimalkan derau yang mengganggu sinyal EKG yang berasal dari berbagai sumber, seperti; derau internal perangkat sensor, interferensi pada jalur listrik, aktivitas otot, dan derau akibat gerakan tubuh/organ lainnya. Makalah ini menerapkan transformasi wavelet untuk mengurangi derau yang mengganggu sinyal EKG untuk mendapatkan sinyal detak jantung yang akurat sesuai dengan kondisi sebenarnya. Data EKG yang digunakan dalam penelitian ini sebanyak tiga data EKG yang telah direkam secara digital yang terdapat di database Aritmia MIT-BIH. Metodologi yang dilakukan pertama kali adalah menerapkan derau pada sinyal EKG sebagai input system dengan cara menambahkan sinyal derau WGN dengan power 1W ke sinyal EKG asli. Kemudian DWT diterapkan untuk mengekstrak sinyal EKG yang telah dikenai derau. Kemudian melakukan seting pada beberapa parameter DWT, seperti misalnya; pemilihan threshold (rule, type, rescaling), tingkat dekomposisi, dan jenis wavelet, untuk mendapatkan sinyal keluaran berupa sinyal denoised dari EKG yang paling akurat. Langkah terakhir adalah membandingkan semua hasil berdasarkan perubahan parameter-parameter DWT terhadap seluruh data input. Hasil terbaik dari proses denoising sinyal EKG menggunakan DWT diperoleh dari penggunaan wavelet Symlet, decomposition level sebesar 3, soft thresholding, pada rule thresholding rigrsure.

Kata kunci : denoising, EKG, sinyal, wavelet.

\section{INTRODUCTION}

The heart is considered the most important organ of our body that controls the circulation of blood throughout the body. Understanding how it works was a

\footnotetext{
* Corresponding Author.

Email: octaheriana@gmail.com

Received: June 16, 2017; Revised: July 21, 2017

Accepted: July 24, 2017; Published: August 31, 2017

(C) 2017 PPET - LIPI
}

meaningful field of study since many years ago. As technology develops, measured heartbeat signals can be further analyzed in order to know the health condition of a person. This measured signal is called Electrocardiogram (ECG) that is a heart signal which represents the electrical activity [1] which in turn represents the physiology and statistical properties of the signal that change over time.

The challenge of ECG signal measurement and analysis is how to remove the noises imposed on the 
signal that is interfered from many different sources. The main noise sources in ECG signal measurement are sensor devices, power line interference, muscle activity, and body movements. The corruption of noises in the ECG signal may affect its amplitude and frequency and may cause problems to detect the actual abnormality. When the noise source is accurately described and understood, the filtering technique will be better and efficient to be designed in noise removal while maintaining the main information or original signal uncorrupted or affected, and the accuracy of the signal can be increased.

Discrete Wavelet Transform (DWT) has such developed forms, Double Density Discrete Wavelet Transform (DDDWT), Dual Tree Discrete Wavelet Transform (DTDWT) and Double Density Dual Tree Discrete Wavelet Transform (DDDTDWT) techniques [2] can be implemented to reduce the noises in ECG signal. Another method is by estimating ECG signal using adaptive method for denoising using widrow hoff LMS algorithm [3], and preconditioned versions NLMS and TDLMS algorithms [4]. DWT can also be implemented by Digital Signal Processing (DSP) module or using Field Programmable Gate Array (FPGA) embedded system module for analyzing, designing and evaluating a pre-processing stage of ECG signal [5]. The DWT has more advantages in signal denoising process because it can analyze the signals in time domain and in frequency domain as well, and can analyze signals in different structures, and also capable of analyzing certain features of input data than other analysis methods that might be inaccurate.

This paper explores wavelet transform to reduce the noise imposed on the ECG signal to get a closely actual heart signal. ECG data used in this research are digitized recorded ECG data obtained from MIT-BIH (MIT and Beth Israel Hospital Medical Centre) Arrhythmia Database. Since most of ECG data recorded from MIT$\mathrm{BIH}$ are in good condition, we need to disrupt the ECG data to become noisy ECG signal. A common way to generate noisy signal from its original is by adding WGN [6] into the original EKG signal. WGN does not represent the real noise appearing in ECG signal measurement, but any noise signal can be used to see performance of DWT in signal denoising process. The next process is extracting the original signal from the noisy ECG signal using DWT. Some DWT's parameters [7] such as wavelet family, threshold and types are varied to get the best denoised output signal. Then the results are compared.

\section{SYSTEM DESIGN}

ECG signal denoising is developed using Matlab software which has provided some toolbox of wavelet transform function. The following Figure 1 shows the block diagram of ECG signal denoising process.

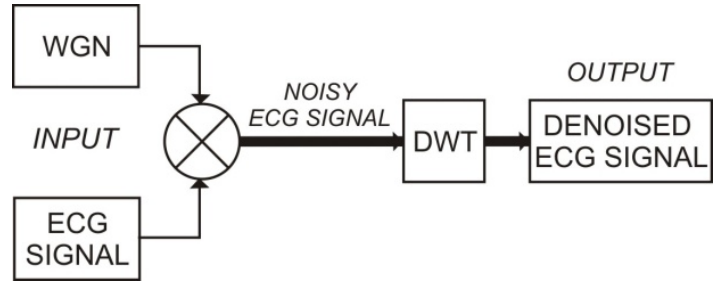

Figure 1. Block Diagram of ECG Signal Denoising System.

The methodology of ECG signal denoising consists of these following sections:

\section{A. Data Input}

ECG data used in this research are the recording data that were digitized and had amplitude over $10 \mathrm{mV}$ range. Most of ECG data were recorded in data format ".dat", therefore they should be converted into the format which is appropriated with the system requirements. The system is developed using Matlab software, and it will process the input data in "double" data formatted. In this paper, we use three different original and digitized ECG recorded signals from MIT$\mathrm{BIH}$, there are: aami3a.dat, aami4a.dat, and aami4b.dat. The differences between aami3a.dat, aami4a.dat and aami4b.dat lie in the waveform, since it is taken from three different subject sources and time.

\section{B. Signal Preprocessing}

Most of ECG data recorded from MIT-BIH are in good condition. Therefore, they need to be disrupted by noise to perform signal denoising process. WGN is imposed to the original ECG signals to become noisy ECG signals.

\section{Discrete Wavelet Transform}

The noisy ECG signals are extracted using DWT algorithm. Some wavelet parameters are varied to get the best denoised output signals. The performance of DWTs are compared by applying different wavelet parameters, such as type of wavelet families, wavelet threshold methods, and type of thresholds [8].

Figure 2 shows the waveform component of ECG signal which the most striking waveform is QRS complex with the wave peak is shown by $\mathrm{R}$ wave. This waveform may be disrupted by such noises that cause the strongest ECG waveform remains unclear [9].

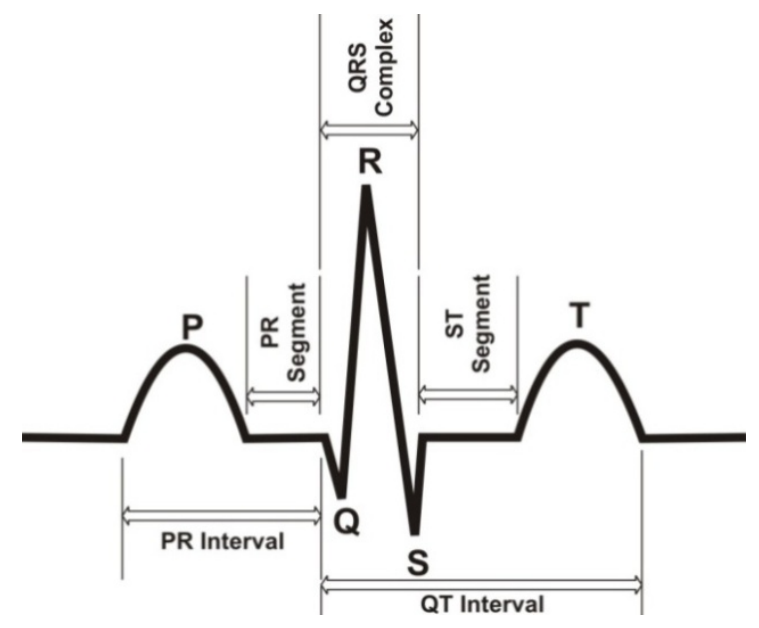

Figure 2. ECG Waveform. 
Wavelet transform is very useful in studying such types of signals. It can analyze the signal in time domain and in frequency domain and it can extract information of the signal in high frequency and low frequency components. This paper implements some wavelet families such as daubechies, symlets, and meyer to analyze which type of wavelet will obtain the best signal denoising result. Selection of wavelet families are based on their wavelet basis shapes and functions applied for denoising of the ECG signals that retaining the waveforms which are closed to their full amplitude.

Block diagram of ECG signal denoising using DWT is given in Figure 3. The DWT signal denoising consists of three important procedures, namely : signal decomposition, DWT coefficients thresholding, and reconstruction of denoised signal.

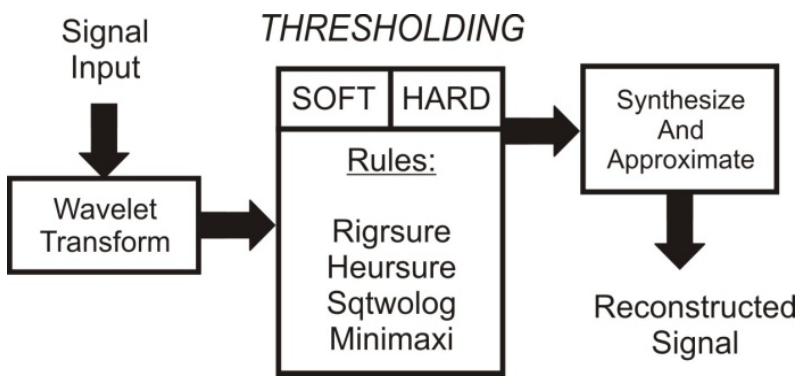

Figure 3. Block Diagram of ECG Signal Denoising using DWT.

The steps of ECG signal denoising can be described as follow [10]:

1) Transform the noisy ECG signal to wavelet domain to find DWT coefficients up to $\mathrm{N}$, a level that is determined by user.

2) Apply thresholding that is varied based on types and rules to obtain the estimated wavelet coefficients that are calculated from 1 to $\mathrm{N}$.

3) Synthesize the ECG signal using the coefficient values from 1 to $\mathrm{N}$ and do signal reconstruction.

In DWT process, the ECG signal is passed through a high pass and a low pass filter. This process is sequenced as much as $\mathrm{N}$ decomposition level which is determined by user. For each decomposition level, the high pass filter produces the approximations coefficient in the wavelet function, while the low pass filter represents the scaling function. The details coefficient and the scale is changed by either up sampling or down sampling by 2 .

Each wavelet family used in this system are Daubechies family db4, db5, db6, and db7, Symlets family sym5, sym6, sym7, sym8, and Meyer wavelet. The thresholding method used in this paper can be either soft or hard depending on the performance of the denoising results. In hard thresholding, the signals that have values smaller than $\delta$ will be dropped to zero. Soft thresholding change the signals to zero when they are smaller than $\delta$, and also subtracts $\delta$ from the values that are larger than $\delta$. Rules determined in the threshold are [7]:

- Rigrsure, a soft threshold evaluator based on (SURF) Stein's Unbiased Risk Estimate.
- Heursure, a combination of rigrsure and sqtwolog rules.

- Sqtwolog, a fixed threshold form which is calculated by universal threshod.

- Minimax, a fixed threshold form that obtain the minimax performance for other parameters.

\section{Performance Measurements}

The performance of DWT denoising processes are measured by analyzing the Signal to Noise Ratio (SNR) of the output signals. Basically SNR is an engineering term for the power ratio between a signal and noise. Wavelet type, threshold method and type selection will vary the value of signal's SNR. The bigger SNR is measured, the better DWT's parameter is selected. The SNR calculation is expressed in terms of the logarithmic decibel scale [10] as shown in Equation (1).

$$
S N R=10 \log _{10}\left[\frac{\sum_{0}^{n_{x-1}}[r(x)]^{2}}{\sum_{0}^{n_{x}-1}[r(x)-t(x)]^{2}}\right]
$$

Here, SNR is signal to noise ratio, where $r(x)$ is original signal; $\mathrm{t}(\mathrm{x})$ is denoised signal; and $\mathrm{x}$ is number of samples in the signals.

\section{DESIGN IMPLEMENTATION AND ANALYSIS}

The following Figure 4, Figure 5 and Figure 6 show the ECG signals of aami3a.dat, aami4a.dat, and aami4b.dat, respectively, with 10000 sampled of signals length which are used as the input of system.

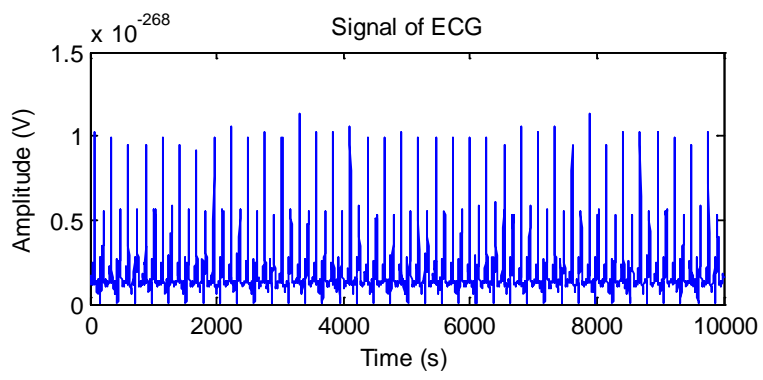

Figure 4. Aami3a.dat ECG Signal.

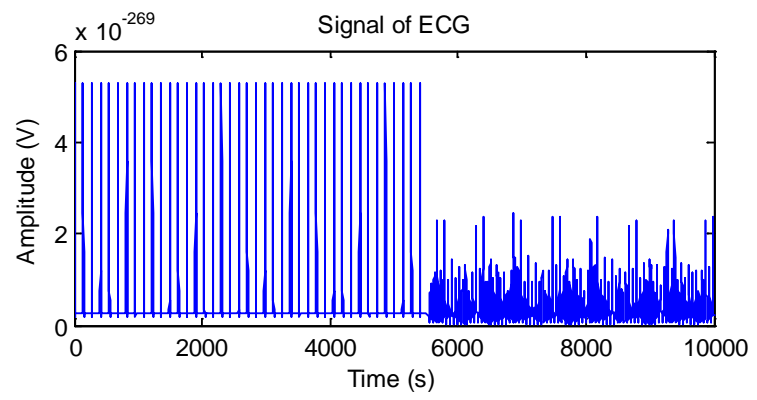

Figure 5. Aami4a.dat ECG Signal.

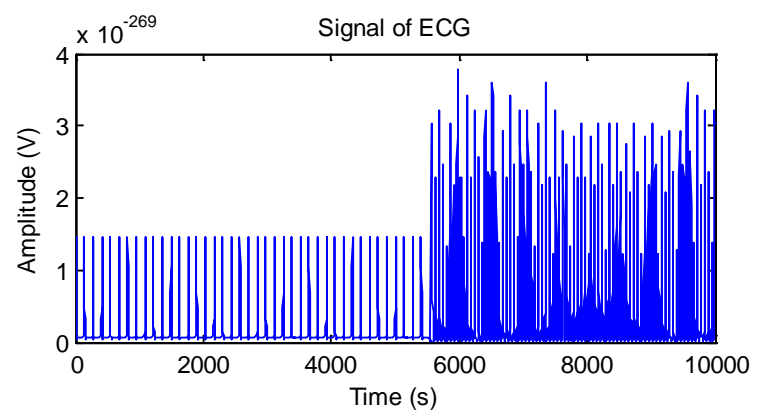

Figure 6. Aami4b.dat ECG Signal. 
The next step is disrupting the original ECG signals by noises. In this case, the WGN is applied to disrupt the original signal. One of ECG signals is zoomed in to see the effect of WGN signal after applied to the original ECG signal. See Figure 7, the aami3a.dat data are then disrupted by $1 \mathrm{~W}$ WGN signal to generate noisy signal as input of the system.

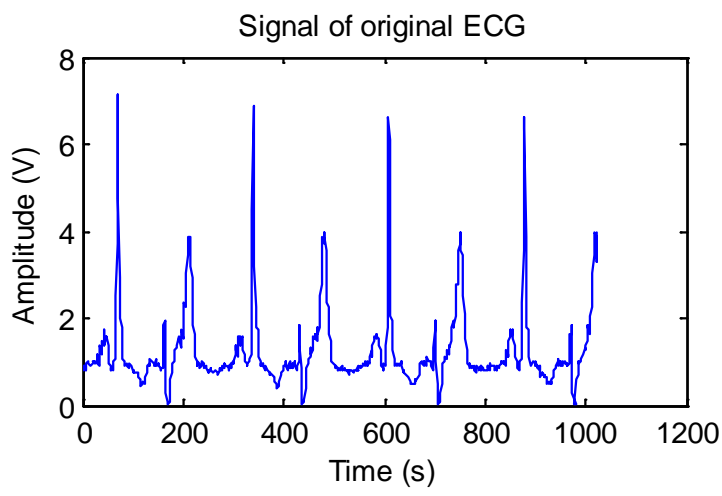

(a)

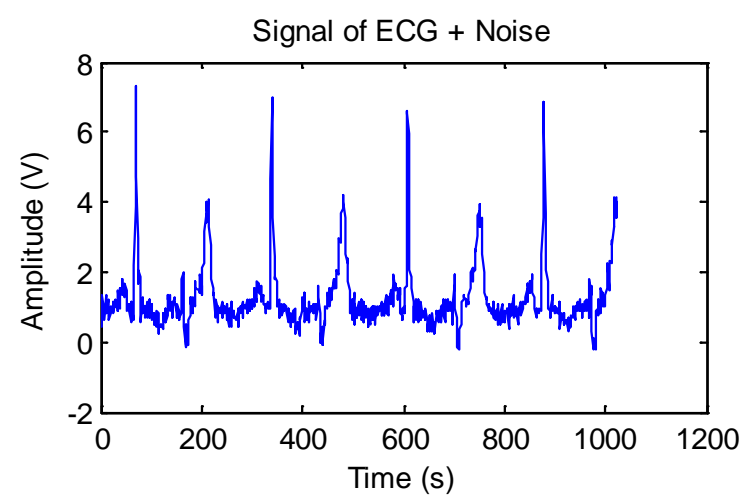

(b)

Figure 7. ECG signal (a) Original and (b) Noisy.

After noisy ECG signals are generated, the DWT is applied to all ECG signals for denoising process. There are 5 parameters should be set to get the best DWT performance for ECG signal denoising, such as : threshold selection rule (rigrsure, heursure, sqtwolog, minimaxi), soft or hard thresholding, multiplicative thresholding rescaling (rescaling process depend on the estimation level of the noise), decomposition level, and desired orthogonal wavelet family. Wavelet family used in this DWT are Daubechies (db4, db5, db6, db7), Symlets (sym5, sym6, sym7, sym8), and Meyer.

In this research, decomposition level is set to 3 for every different parameter. This level is chosen to 3 based on the effectiveness of the process. The following Figure 8 shows one capture of noisy signal of aami3a.dat, the waveform of denoised signal with rigrsure soft threshold and its residual signal, and the waveform of denoised signal with rigrsure hard threshold with its residual signal, in one example of DWT's parameter setting with sym5 wavelet family.

Figure 9 shows the noisy signal of aami4a.dat, the waveform of denoised signal with rigrsure soft threshold and its residual signal, and the waveform of denoised signal with rigrsure hard threshold with its residual signal, in one example of DWT's parameter setting with sym5 wavelet family.

Figure 10 shows the noisy signal of aami4b.dat, the waveform of denoised signal with rigrsure soft threshold and its residual signal, and the waveform of denoised signal with rigrsure hard threshold with its residual signal, in one example of DWT's parameter setting with sym5 wavelet family.

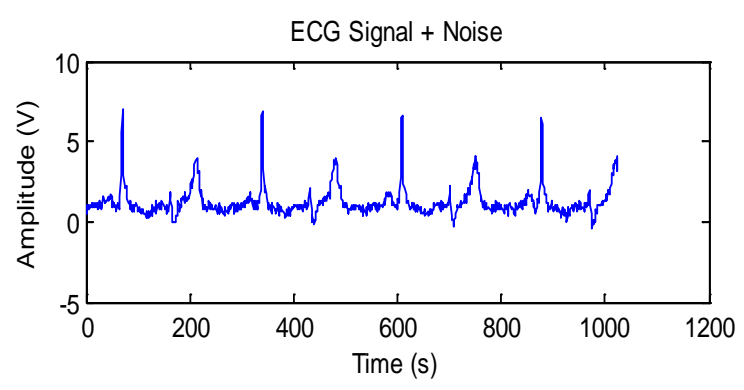

Denoised Signal (Rigrsure, Soft Threshold, Decomposition Level:3, sym5)
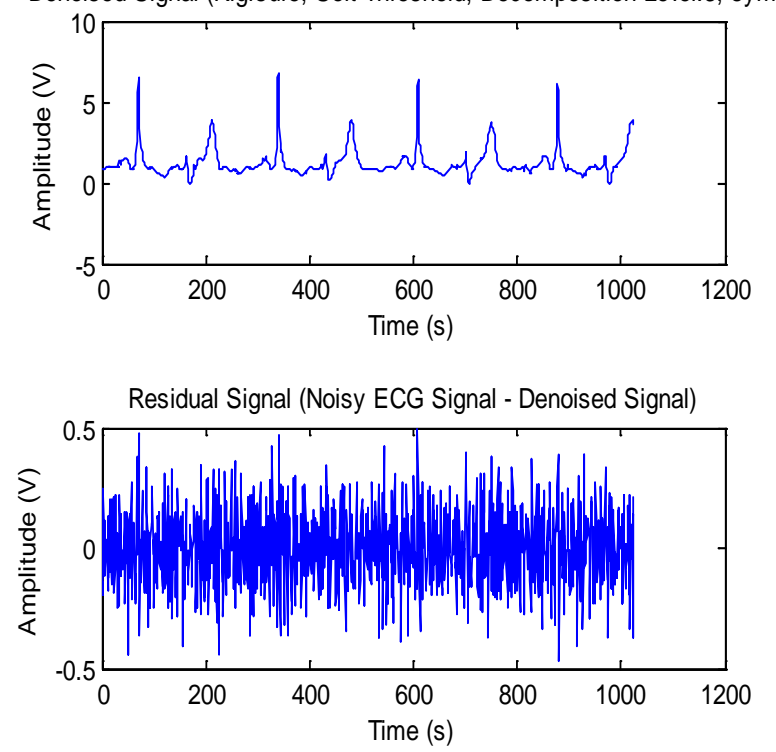

Denoised Signal (Rigrsure, Hard Threshold, Decomposition Level:3, sym5)
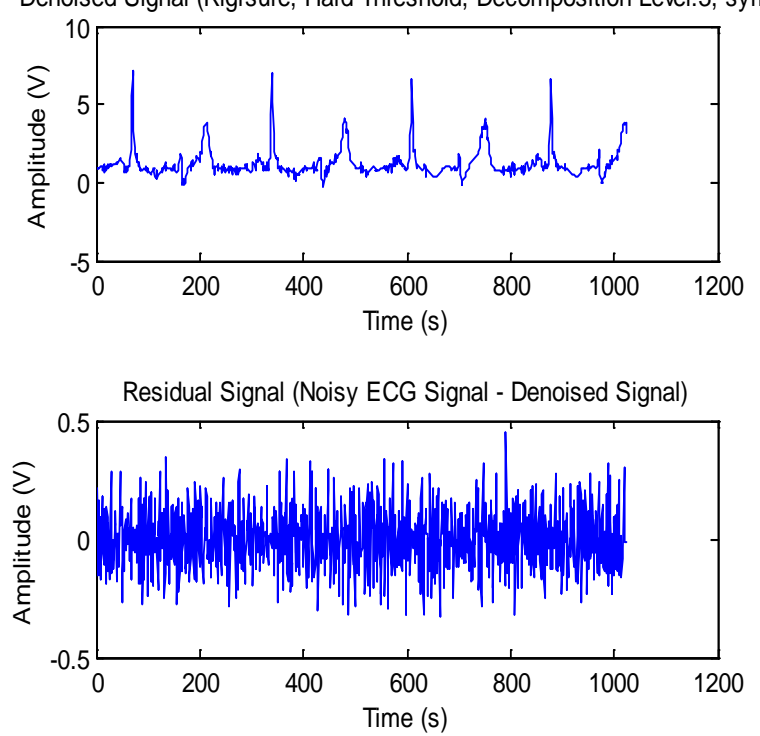

Figure 8. ECG Signal Denoising of Aami3a.Dat Using Symlets 5. 


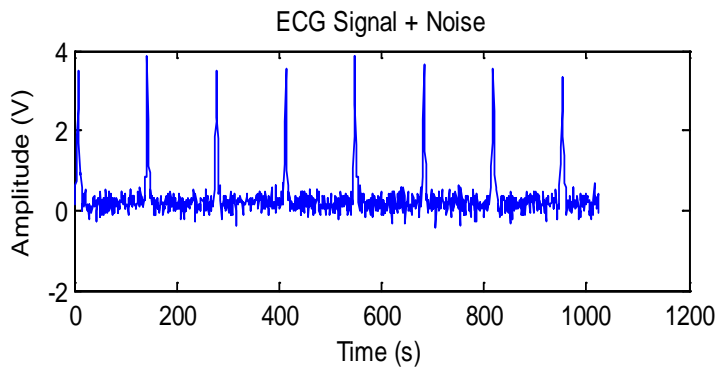

Denoised Signal (Rigrsure, Soft Threshold, Decomposition Level:3, sym7)
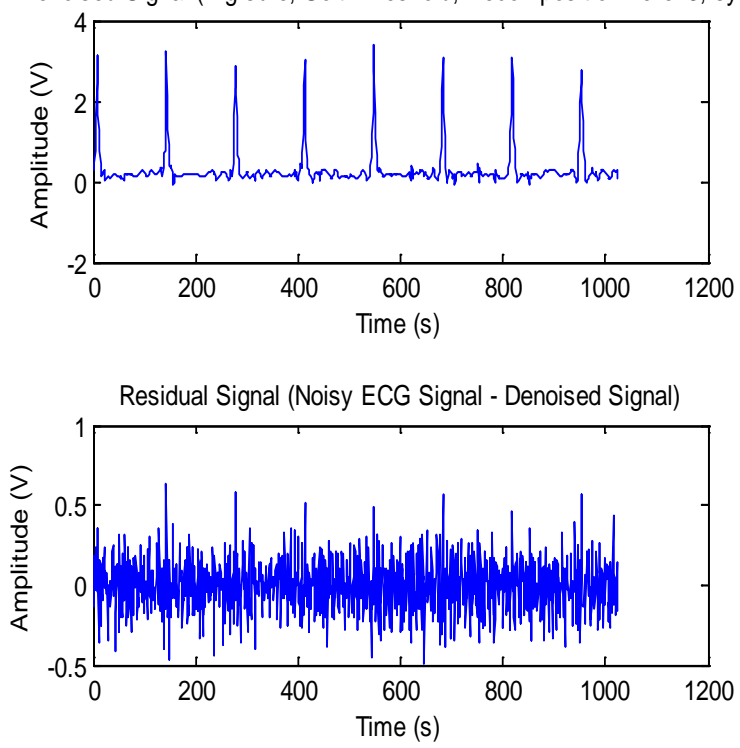

Denoised Signal (Rigrsure, Hard Threshold, Decomposition Level:3, sym7)
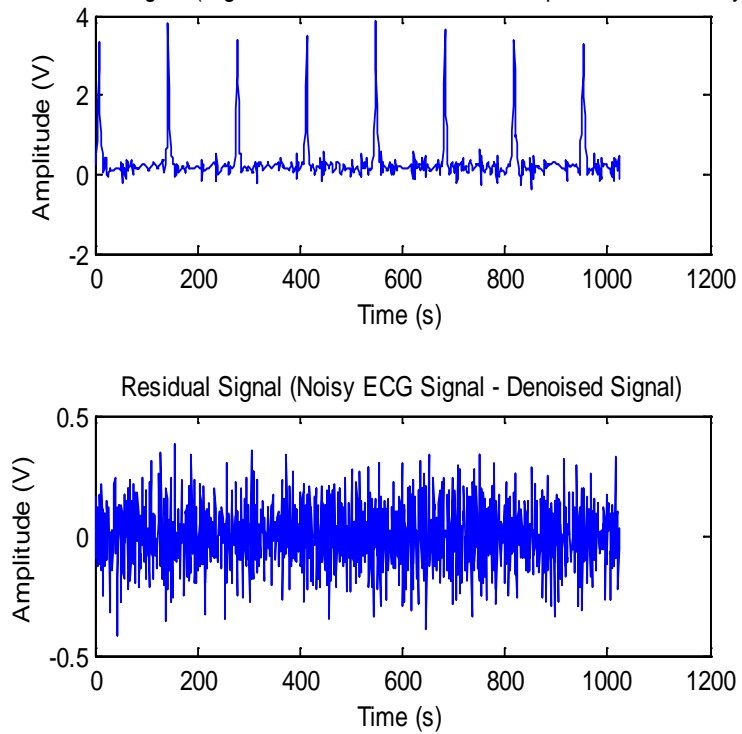

Figure 9. ECG Signal Denoising of Aami4a.Dat Using Symlets 5.

All results are recorded to see which DWT parameter can give the best denoising process. Table 1 shows the values of SNR (dB) of Wavelet Thresholding that are performed on ECG data aami3a .dat from MIT$\mathrm{BIH}$. The best performance is shown by symlets $5 \mathrm{with}$ soft threshold in rigrsure threshold technique with decomposition level $=3$, and SNR $=22.7278$.

Table 2 shows the values of SNR (dB) of Wavelet Thresholding that are performed on ECG data aami4a .dat from MIT-BIH. The best performance is shown by symlets 7 with soft threshold in rigrsure threshold technique with decomposition level $=3$, and $\mathrm{SNR}=$ 15.5300 .

Table 3 shows the values of SNR (dB) of Wavelet Thresholding that are performed on ECG data aami4b .dat from MIT-BIH. The best performance is shown by symlets 5 with soft threshold in rigrsure threshold technique with decomposition level $=3$, and $\mathrm{SNR}=$ 6.3716 .

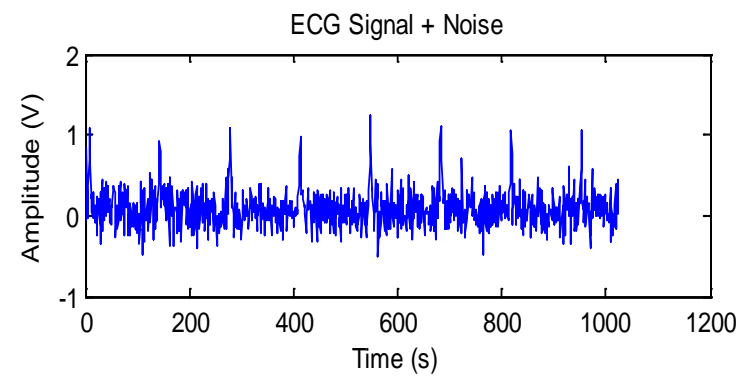

Denoised Signal (Rigrsure, Soft Threshold, Decomposition Level:3, sym5)
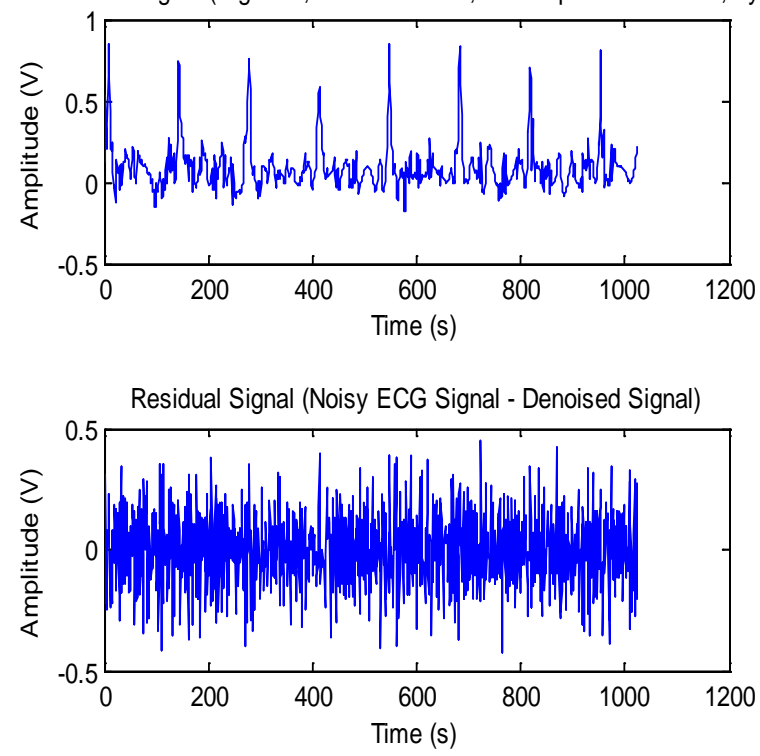

Denoised Signal (Rigrsure, Hard Threshold, Decomposition Level:3, sym5)
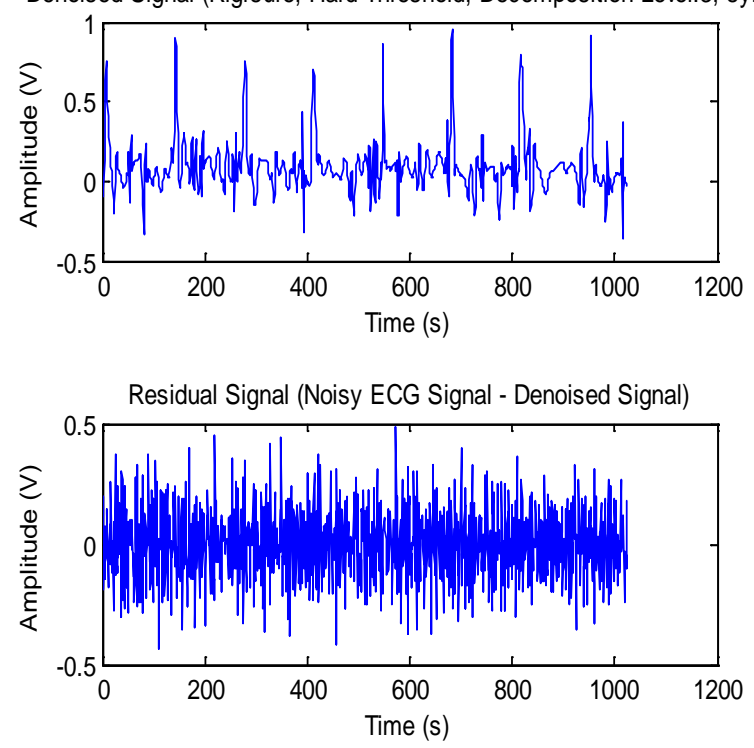

Figure 10. ECG Signal Denoising of Aami4b.Dat Using Symlets 5. 
TABLE 1

VALUES OF SNR (DB) OF WAVELET THRESHOLDING PERFORMED ON AAMI3A.DAT

\begin{tabular}{|c|c|c|c|c|c|}
\hline \multirow{2}{*}{ Name } & $\begin{array}{c}\text { Thres- } \\
\text { hold }\end{array}$ & rigrsure & heursure & sqtwolog & minimaxi \\
\hline \multirow{2}{*}{ db4 } & Hard & 20.83 & 22.16 & 20.02 & 21.37 \\
\cline { 2 - 6 } & Soft & 22.49 & 21.91 & 18.39 & 20.22 \\
\hline \multirow{2}{*}{ db5 } & Hard & 20.13 & 21.38 & 20.15 & 21.07 \\
\cline { 2 - 6 } & Soft & 22.36 & 22.24 & 17.46 & 19.18 \\
\hline \multirow{2}{*}{ db6 } & Hard & 19.68 & 21.10 & 20.15 & 21.04 \\
\cline { 2 - 6 } & Soft & 22.14 & 21.20 & 16.76 & 19.78 \\
\hline \multirow{2}{*}{ db7 } & Hard & 20.09 & 21.60 & 19.14 & 20.85 \\
\cline { 2 - 6 } & Soft & 22.12 & 21.28 & 16.70 & 18.73 \\
\hline \multirow{2}{*}{ sym5 } & Hard & 21.41 & 21.81 & 20.43 & 22.18 \\
\cline { 2 - 6 } & Soft & $22.72 *$ & 21.53 & 17.92 & 20.29 \\
\hline \multirow{2}{*}{ sym6 } & Hard & 20.59 & 21.53 & 20.76 & 21.27 \\
\cline { 2 - 6 } & Soft & 22.39 & 21.80 & 18.36 & 20.36 \\
\hline \multirow{2}{*}{ sym7 } & Hard & 21.08 & 21.56 & 20.56 & 21.96 \\
\cline { 2 - 6 } & Soft & 21.65 & 21.45 & 17.67 & 19.42 \\
\hline \multirow{2}{*}{ sym8 } & Hard & 20.86 & 20.94 & 20.86 & 21.43 \\
\cline { 2 - 6 } & Soft & 22.03 & 21.6 & 18.46 & 20.27 \\
\hline \multirow{2}{*}{ Meyer } & Hard & 21.35 & 21.65 & 19.98 & 20.47 \\
\cline { 2 - 6 } & Soft & 20.56 & 21.93 & 17.17 & 19.02 \\
\hline
\end{tabular}

* The best result is shown by sym5 with soft threshold and rigrsure rule, and $\mathrm{SNR}=22.72$

TABLE 2

VALUES OF SNR (DB) OF WAVELET THRESHOLDING PERFORMED ON AAMI4A.DAT

\begin{tabular}{|c|c|c|c|c|c|}
\hline \multirow{2}{*}{ Name } & $\begin{array}{c}\text { Thres- } \\
\text { hold }\end{array}$ & rigrsure & heursure & sqtwolog & minimaxi \\
\hline \multirow{2}{*}{$\mathrm{db} 4$} & Hard & 12.30 & 15.06 & 14.38 & 14.97 \\
\cline { 2 - 6 } & Soft & 14.69 & 14.77 & 11.62 & 13.48 \\
\hline \multirow{2}{*}{$\mathrm{db} 5$} & Hard & 12.98 & 13.54 & 14.38 & 13.81 \\
\cline { 2 - 6 } & Soft & 14.16 & 12.61 & 10.37 & 13.29 \\
\hline \multirow{2}{*}{$\mathrm{db} 6$} & Hard & 12.87 & 14.75 & 12.94 & 13.62 \\
\cline { 2 - 6 } & Soft & 14.87 & 12.83 & 10.21 & 12.18 \\
\hline \multirow{2}{*}{$\mathrm{db} 7$} & Hard & 13.53 & 13.22 & 12.36 & 13.66 \\
\cline { 2 - 6 } & Soft & 14.71 & 12.21 & 9.741 & 12.35 \\
\hline \multirow{2}{*}{ sym5 } & Hard & 12.15 & 14.25 & 14.01 & 14.10 \\
\cline { 2 - 6 } & Soft & 14.82 & 13.02 & 10.63 & 13.22 \\
\hline \multirow{2}{*}{ sym6 } & Hard & 13.81 & 15.14 & 14.25 & 13.93 \\
\cline { 2 - 6 } & Soft & 15.13 & 14.04 & 9.856 & 13.51 \\
\hline \multirow{2}{*}{ sym7 } & Hard & 13.80 & 12.59 & 13.69 & 14.76 \\
\cline { 2 - 6 } & Soft & $15.53 *$ & 13.36 & 10.62 & 13.44 \\
\hline \multirow{2}{*}{ sym8 } & Hard & 13.00 & 14.85 & 13.48 & 14.35 \\
\cline { 2 - 6 } & Soft & 13.89 & 12.96 & 10.29 & 12.79 \\
\hline \multirow{2}{*}{ Meyer } & Hard & 12.14 & 13.44 & 12.13 & 13.52 \\
\cline { 2 - 6 } & Soft & 13.75 & 12.78 & 9.78 & 12.27 \\
\hline
\end{tabular}

* The best result is shown by sym7 with soft threshold and rigrsure rule, and $\mathrm{SNR}=15.53$

TABLE 3

VALUES OF SNR (DB) OF WAVELET THRESHOLDING PERFORMED ON AAMI4B.DAT

\begin{tabular}{|c|c|c|c|c|c|}
\hline \multirow{2}{*}{ Name } & $\begin{array}{c}\text { Thres- } \\
\text { hold }\end{array}$ & rigrsure & heursure & sqtwolog & minimaxi \\
\hline \multirow{2}{*}{ db4 } & Hard & 5.41 & 5.50 & 4.96 & 4.04 \\
\cline { 2 - 6 } & Soft & 6.34 & 5.02 & 4.56 & 5.77 \\
\hline \multirow{2}{*}{ db5 } & Hard & 4.28 & 4.73 & 4.54 & 3.84 \\
\cline { 2 - 6 } & Soft & 5.30 & 5.12 & 4.83 & 4.97 \\
\hline \multirow{2}{*}{ db6 } & Hard & 1.89 & 4.65 & 4.69 & 4.09 \\
\cline { 2 - 6 } & Soft & 5.80 & 4.87 & 4.79 & 5.20 \\
\hline \multirow{2}{*}{ db7 } & Hard & 2.63 & 5.05 & 4.52 & 3.15 \\
\cline { 2 - 6 } & Soft & 6.04 & 4.74 & 5.03 & 4.31 \\
\hline \multirow{2}{*}{ sym5 } & Hard & 4.39 & 4.78 & 4.93 & 4.22 \\
\cline { 2 - 6 } & Soft & $6.37 *$ & 5.09 & 4.68 & 5.39 \\
\hline \multirow{2}{*}{ sym6 } & Hard & 3.69 & 5.71 & 5.65 & 4.33 \\
\cline { 2 - 6 } & Soft & 5.57 & 5.20 & 4.99 & 5.71 \\
\hline \multirow{2}{*}{ sym7 } & Hard & 3.34 & 5.51 & 4.80 & 4.18 \\
\cline { 2 - 6 } & Soft & 6.11 & 5.09 & 4.93 & 5.23 \\
\hline \multirow{2}{*}{ sym8 } & Hard & 3.35 & 5.41 & 5.37 & 3.21 \\
\cline { 2 - 6 } & Soft & 4.52 & 5.21 & 4.46 & 4.81 \\
\hline \multirow{2}{*}{ Meyer } & Hard & 3.07 & 5.02 & 5.19 & 3.71 \\
\cline { 2 - 6 } & Soft & 6.24 & 4.74 & 4.93 & 4.99 \\
\hline
\end{tabular}

* The best result is shown by sym5 with soft threshold and rigrsure rule, and $\mathrm{SNR}=6.37$

The DWT system for ECG signal denoising is developed using Matlab. As a future development, if it needs to be applied in real time case, it should be developed in other programming language, and implemented in embedded hardware system i.e. FPGA board.

\section{CONCLUSION}

Based on wavelet signal denoising implementation to three different ECG signals and comparison of their SNR values that are obtained from signal denosing using Daubechies, Symlets and Meyer family wavelet, it can be concluded that the hard threshold did not give good denoising performance. The best denoising results of aami3a.dat anad aami4b.dat are obtained by symlets 5 with soft threshold in rigrsure threshold. In the experiment of aami4a.dat shows that the best denoising result is obtained by symlets $7 \mathrm{w}$ ith soft threshold in rigrsure threshold. Therefore, by analyzing the results, the best DWT parameter for ECG signal denoising is obtained obviously by Symlet wavelet family when the decomposition level is set to 3, with soft thresholding, in rigrsure thresholding rule.

\section{ACKNOWLEDGEMENT}

We would like to say thank you to King Fahd University of Petroleum and Minerals, Saudi Arabia for the Matlab software facilities.

\section{REFFERENCE}

[1] J. Muthuswamy, Standard Handbook of Biomedical Engineering and Design, Chapter 18 Biomedical Signal Analysis, Tempe, Arizona: McGraw-Hill, 2003.

[2] Shemi P.M. and Shareena E.M., "Analysis of ECG signal denoising using discrete wavelet transform", in Proceeding 2nd IEEE International Conference on Engineering and Technology (ICETECH), 2016 pp. 713-718.

[3] G. Makwana and L. Gupta, "De-Noising of Electrocardiogram (ECG) with adaptive filter using MATLAB", in Proceeding Fifth International Conference on Communication Systems and Network Technologies, 2015, pp. 511-514.

[4] S. Javed and N. A. Ahmad, "An adaptive noise cancelation model for removal of noise from modeled ECG signals", in Proceeding IEEE Region 10 Symposium, 2014, pp. 471-475.

[5] E. M. E. Hassan and M. Karim, "An FPGA-based implementation of a p re-processing stage for ECG signal analysis using DWT", in Proceeding Second World Conference on Complex Systems (WCCS), 2014, pp. 649-654.

[6] S. M. R. Islam, X. Huang, D. Sharma, "Wavelet based denoising algorithm of the ECG signal corrupted by WGN and poisson noise", in Proceeding International Symposium on Communications and Information Technologies (ISCIT), 2012, pp. 165-168.

[7] M. Misiti, Y. Misiti, G. Oppenheim, and J. M. Poggi, Wavelet Toolbox 4 User's Guide, Natick, United States: The Math Works Inc., 2004.

[8] A. B. H. A. Mitiche, L. Mitiche, and H. Naimi, "Three levels discrete wavelet transform elliptic estimation for ECG denoising", in Proceedings 4th International Conference on Control Engineering \& Information Technology (CEIT-2016), 2016, pp. 1-5.

[9] B. Xhaja, E. Kalluci, L. Nikolla, "Wavelet transform applied in ECG signal processing”, European Scientific Journal April 2015 edition, Vol.11, No.12, pp. 305-312, April, 2015.

[10] C. Sawant and H. T. Patii, "Wavelet based ECG signal denoising", in Proceeding First International Conference on Networks \& Soft Computing (ICNSC2014), 2014, pp. 20-24. 